\title{
A Note on Targets of A'-movement in the Left Periphery of German Sentences*
}

Josef Bayer

University of Konstanz

\section{The Left edge of the German clause}

In his 2002 monograph Minimalistische Syntax, Günther Grewendorf proposes a C-domain for German which is positionally richer than traditionally assumed in generative syntax. In following leading ideas by Rizzi (1997), Grewendorf assumes a structure for German in which the C-domain may be split up into different functional positions among which there are two potential landing sites for wh-phrases. There is a lower one which is the specifier of the so-called FINITE PHRASE (SpecFinP), and a higher one which is the specifier of the so-called FOCUS PHRASE (SpecFocP). These two will figure in the following discussion.

According to Grewendorf, movement of a wh-phrase to SpecFinP is like any other movement to the familiar "Vorfeld" of the German clause. It is triggered by an EPP-requirement. The wh-phrase acquires its operator scope only after another step from SpecFinP to SpecFocP. Thus, the actual variable which is bound by the wh-phrase is in SpecFinP (or is transmitted from there to the foot of the chain). (1) shows the relevant steps of wh-movement in a simplex interrogative clause.

\footnotetext{
* I am indebted to Werner Frey for discussions about some of the issues of the present contribution. Many thanks also to Eric Fuß and Patrick Brandt for their suggestions which led to various improvements. The responsibility for any errors and misconceptions is my own. The present work has been supported by the Deutsche Forschungsgemeinschaft via the Konstanz Sonderforschungsbereich 471 Variation and Evolution in the Lexicon.
} 
(1)

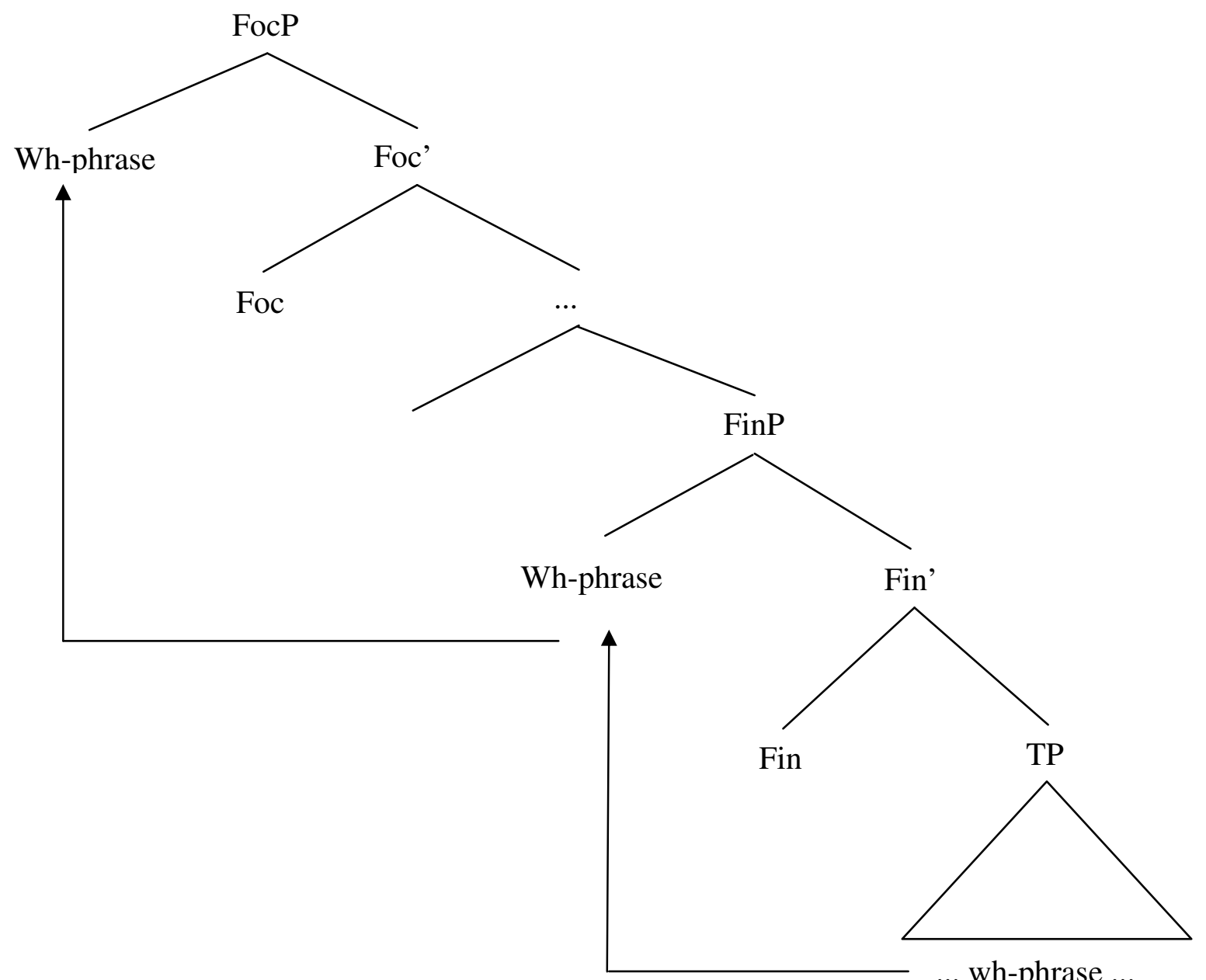

\section{Weak Crossover}

A major motivation for this distinction of landing sites comes from data on WEAK CROSSOVER (WCO), i.e. an ungrammaticality that arises due to a variable which is coindexed with a pronoun to its left such that the pronoun does not c-command the variable (as is the case in STRONG CROSSOVER). It has been observed by Grewendorf (1988), Haider (1993) and various other syntacticians that German displays clear WCO-effects only in long wh-movements. Whmovement in the simplex clause, short wh-movement, does not lead to a comparable loss of grammaticality. ${ }^{1}$ The following examples are from Grewendorf (2002).

(2) Wen ${ }_{1}$ hat $\operatorname{sein}_{1}$ bester Freund $t_{1}$ an die Polizei verraten? who has his best friend to the police betrayed "*Who did his best friend betray to the police?" (grammatical in German)

(3) *Welchen Studenten ${ }_{1}$ hat $\operatorname{sein}_{1}$ Vater gesagt, dass Maria $t_{1}$ gesehen hat? which student has his father said that Maria seen has “*Which student did his father say that Maria has seen?” (ungrammatical in German)

\footnotetext{
${ }^{1}$ Although the constructions appear to be semi-grammatical or marked for certain speakers, a judgement which I do no share myself.
} 
Following Lasnik and Stowell's (1991) analysis of the absence of a WCO-effect in English relative clauses as in $J o h n_{1}$, who his $_{1}$ father likes $\mathrm{t}_{1}$, he suggests that the WCO-effect appears only if the A'-binder has been moved to a genuine operator position. The distinction between SpecFinP and SpecFocP as potential landing sites for wh-phrases enables him to argue that only SpecFocP but not SpecFinP is a genuine operator position. The absence of the WCOeffect in (2) follows because in crossing over the possessive pronoun sein, wen has been moved to the non-offending position SpecFinP and only later to SpecFocP. The presence of the WCO-effect in (3) follows because in crossing over the possessive pronoun sein, wen has now been moved from the potentially offending position SpecFocP to the matrix clause's SpecFocP. One background assumption here is that the constraint against improper movement prevents movement from SpecFocP to SpecFinP. Grewendorf's suggestion is that in this situation the FinP of the matrix clause is not projected at all. A more natural solution comes to mind rather easily: Since the wh-phrase does not terminate in the first position which is reached after A'-movement, one could equally well expect that FinP will not be projected in the embedded clause. Thus, the wh-phrase would move to SpecFocP directly. According to Grewendorf's assumptions this solution is not viable, however, because we would lose the explanation for the absence of the WCO-effect in the simplex clause. The new account of whmovement in German is, thus, characterized by the two generalizations in (4).

a. The target of short wh-movement is the non-operator position SpecFinP.

b. The target of long wh-movement is the operator position SpecFocP.

Another important aspect of the analysis is that EPP-checking is assumed only for SpecFinP, i.e. for the position whose adjacent head hosts the finite verb. Once wh-movement has passed the complementizer, there is no EPP-checking, and the assumption is that in this case wh-movement leads directly to SpecFocP. The contrast which is adduced in support of this is the one shown in (5), the judgments being Grewendorf's. ${ }^{2}$
a.
?Wen $_{1}$ glaubt Maria [FinP $\mathrm{t}_{1}$ who believes Maria hat $\operatorname{sein}_{1}$ bester Freund $t_{1}$
has his best friend an die Polizei verraten]? ??Wen glaubt Maria [FocP $_{1}$ dass $\operatorname{sein}_{1}$ bester Freund $t_{1}$ an die Polizei
b. that his best friend to the police who believes Maria verraten hat]? betrayed has

While the distinction between a low A'-position such as SpecFinP and a high A'-position such as SpecFocP strikes me as well-motivated in general, I do not share the judgments in (5). In my view both questions are equally grammatical, i.e. none of them involves a WCOviolation. The difference seems to rest in the increased complexity of (5b) as compared to (5a). ${ }^{3}$ On the other hand there is evidence that movement across the overt complementizer does target a higher A'-position such as SpecFocP. ${ }^{4}$ If I am right with this evaluation, we have to look for another explanation of the partial absence of the WCO-effect in German. In the next section I will sketch an alternative which can be reconciled with Grewendorf's general and in my view correct distinction as described in (4).

\footnotetext{
${ }^{2}$ The examples are Grewendorf's (207a,b) which I enrich here with labelled brackets for the sake of clarity.

${ }^{3}$ This would be especially so, if one were to follow Reis' (1995) arguments in favor of analyzing the V1construction glaubt Maria in (5a) as a parenthesis. If Reis is correct, only (5b) shows genuine long movement. ${ }^{4}$ See, for instance, Bayer $(2001 ; 2005 \mathrm{a}, \mathrm{b})$ and Frey (2005a). Frey suggested the term Kontrast Phrase (KontrP) instead of FocP, which could help avoiding the association that material is moved to SpecFocP for focus checking. I assume that in German information focus must be checked in the middle field to the left of the verb as in most languages with a head-final VP. The transfer to SpecFocP or SpecKontrP must then have an independent reason.
} 


\section{A-Scrambling}

Grewendorf and Sabel (1999) suggest with many others that scrambling in German is some kind of A'-movement, and that as a consequence wh-movement cannot take the scrambling position as the position of the variable to be bound by the wh-operator. ${ }^{5}$ Thus, the absence of WCO effects with short wh-movement has to be relegated to the left peripheral positions discussed in the previous section. Various linguists have argued, however, that at least a subset of scrambling operations in German shows properties of A-movement. ${ }^{6}$ From this perspective, the absence of a WCO-effect as seen in (2) can be explained quite naturally: A-movement of the object may cross the subject without interfering with variable binding. Under the plausible assumption that wh-scrambling is not performed for the purpose of wh-checking, there is no reason for the scrambling trace to count as a variable, which of course needs to be A-free, i.e. must not be coindexed with a pronoun in some A-position. This is shown in (6), a reanalysis of (2) in which the step from $t_{1}$ to $t^{\prime}$ s should be conceived of as an instance of A-scrambling.

$\mathrm{Wen}_{1}$ hat $\mathrm{t}^{\prime}{ }_{1} \operatorname{sein}_{1}$ bester Freund $\mathrm{t}_{1}$ an die Polizei verraten?

The correlation between the scrambling option and the WCO-circumvention which is found in German but not in English should be a strong conceptual motivation for retaining such an approach. The fact that long wh-movement may induce a WCO-violation as seen in (3) can be accounted for by noticing that German does not allow scrambling (or at least Ascrambling) out of CP. In (3) A-scrambling of the wh-object would not rescue the derivation because the WCO-violation would invariably occur in the matrix clause. ${ }^{7}$ The predictions are exactly the same as those made by Grewendorf's system. This is not so in (5b), however. Grewendorf predicts a WCO-effect due to direct movement to SpecFocP, whereas the Ascrambling approach predicts that the structure is rescued by first scrambling the wh-operator, in the present case wen, across the potentially offending pronoun, in the present case sein. Since to my ear (5b) is perfectly grammatical, I conclude that the A-scrambling approach should be accepted.

\section{Do landing sites determine operator status?}

Provided that there are at least two different landing sites for A'-movement, the next question to ask is whether these landing sites determine the operator status of the phrase to be moved. Recall the assumption in Grewendorf (2002) that operator status is yielded by movement to SpecFocP but not by movement to SpecFinP. Material in the latter can only agree for an EPPor V2-feature. On the other hand, movement beyond the complementizer should invariably invoke SpecFocP. The expectation is nourished that movement to SpecFocP assigns operator

\footnotetext{
${ }^{5}$ The reason is a violation of the constraint against improper movement, as discussed in detail by Müller and Sternefeld (1993).

${ }^{6}$ For example Fanselow (1990), Bayer (1996), Hinterhölzl and Pili (2003) among many others. Bayer and Kornfilt (1994) present a number of arguments against scrambling as A'-movement. There is also a more marked type of A'-scrambling which has been referred to by notions like "focus scrambling" and "I-topicalization". This second type does not concern us here.

${ }^{7}$ Alternatively one could argue that in this situation scrambling does not occur as it would be a superfluous step. However, in this case some look-ahead device is required by which it is determined whether or not a crossover violation will occur in an upper cycle. Given that wh-movement is in terms of linear distance ,unbounded“ (cf. Welchen Studenten ${ }_{1}$ hat sein ${ }_{1}$ Vater gesagt, dass Waldemar meint, dass Ernestine glaubt, dass ... Maria $\mathrm{t}_{1}$ gesehen hat?) a solution which involves such a powerful device seems to be illusory. Thanks to Patrick Brandt and Eric Fuß for drawing my attention to this problem. The issue is a really interesting one. For initial discussion cf. Bayer (2005a, §9).
} 
status to the affected material. ${ }^{8}$ I would like to demonstrate now that neither of these expectations is fulfilled.

Assume a V2-complement as in (7) in which the subject has been raised to SpecFinP for EPPor V2-checking.

(7) Wer hat behauptet [FinP Heinz-Rüdiger sei in die Toskana ausgewandert]? who has asserted Heinz-Rüdiger be subj $_{1}$ in the Tuscany emigrated

If the subject Heinz-Rüdiger in (7) is replaced by the wh-word wer ("who"), we should expect association with the matrix wh-operator. The reason is that the lower wh-word has not taken an operator or scope position yet. Thus, replacement of the name by a wh-word should lead to a well-formed multiple question. However, (8) is clearly deviant.

$$
\begin{gathered}
\text { *Wer hat behauptet [FinP wer sei in die Toskana ausgewandert]? } \\
\text { who has asserted who be } \text { subj }_{\text {in the Tuscany emigrated }}
\end{gathered}
$$

There are two conclusions one can draw from this: (i) The lower wer has been moved one step up into SpecFocP and has therefore undergone scope freezing, which leads to a semantic selectional conflict with the matrix predicate. Alternatively, (ii) wer has taken scope in SpecFinP and has undergone scope freezing right there, which leads to the same selectional conflict. I believe that the first conclusion is not very plausible. Projectional economy would bar the projection of the FocP-layer if there is no reason for the wh-word to take scope in the lower clause. Apart from this, SpecFinP must be a scope position for other types of operators such as quantified DPs. This is at least the most parsimonious assumption. ${ }^{9}$ So the conclusion would be that even SpecFinP is a possible scope position, and that a wh-phrase which moves there for reasons of EPP-checking would in this position automatically display wh-scope. ${ }^{10}$

One can equally show that movement to SpecFocP does not automatically assign operator status to the affected material. Relative clauses are a case in point. Given the assumption that long A'-movement from a CP (with the overt complementizer dass) has to target SpecFocP one could be led to the expectation that long relativization exhibits a WCO-effect. This expectation is not borne out, however. (9) is, with the intended interpretation, a grammatical sentence, showing at best "weakest" crossover.

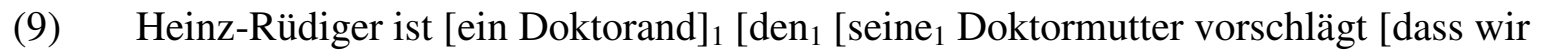
Heinz-Rüdiger is a PhD-student who his adviser proposes that we bald $t_{1}$ zu einem Kolloquium einladen sollten]]]

soon to a colloquium invite should "Heinz-Rüdiger is a $\mathrm{PhD}$-student who his adviser proposes that we should soon invite for a colloquium"

\footnotetext{
${ }^{8}$ We need to be careful with this interpretation because Grewendorf (2002) is not explicit about it.

${ }^{9}$ I do not want to argue against an extra step of ,,short QR“ which could be motivated for purely semantic reasons. I see, however, no empirical justification for identifying such an operation with the syntactically motivated landing sites which the split-C system has in stock.

${ }^{10}$ One worry with this conclusion could be that one loses the explanation of long wh-movement from V2complements. This worry is likely to disappear if one follows Reis (1995) in assuming that the bridge construction in these cases can be treated as a special kind of parenthesis (see also note 3 ).
} 
(9) shows that if the relative pronoun is a null constant as Lasnik and Stowell (1991) have argued, it remains such a null constant whichever A'-position it moves to. In short, the determinant of \pm operator status is the phrase which is moved rather than the landing site.

\section{On the relevance of different $A^{\prime}$ '-positions}

In this section I would like to show that my previous concerns do not in any way discredit the assumption of different A'-landing sites for German. Lenerz (1994:162) has drawn the attention to examples such as (10).

(10) Ihr Geld ist ja nicht weg, meine Damen und Herren.

your money is PRT not away my ladies and gentlemen.

Es haben jetzt nur andere.

it have now only others

"Your money hasn't gone, ladies and gentlemen. It is only in the possession of others"

The positioning of an object-es in SpecFinP is remarkable because it shows that the ban on espreposing to the "Vorfeld" that had first been pointed out by Travis (1984) is not absolute. The critical sentence can be changed into a so-called extraction from V2 without any loss of grammaticality.

(11) Es glaube ich haben jetzt nur andere.

it believe I have now only others

However as Frey (2005a:153) has pointed out, extraction of es from a dass-CP leads to severe ungrammaticality. Changing (11) into a case of genuine long extraction as in (12) would be inconceivable. ${ }^{11}$

(12) *Es glaube ich dass jetzt nur andere haben.

it believe I that now only others have

The same is true for other non-focusable or non-contrastable material. In the first class, there would be the indefinite subject pronoun man ("one", similar to French on). In the second class, there would be speaker oriented adverbs like leider ("unfortunately"), which Frey has shown cannot be contrasted. Consider Frey's (2005a) examples in (13a) and (13c) to which I add the grammatical example in (13b).

(13) a. Leider ${ }_{1}$ hat $\mathrm{t}_{1}$ keiner dem alten Mann geholfen. unfortunately has nobody the old man helped

"Unfortunately, nobody helped the old man"

b. Leider ${ }_{1} \quad$ sagte Karl hat $\mathrm{t}_{1}$ dem alten Mann keiner geholfen. unfortunately said Karl has the old man nobody helped

c. $\quad$ *Leider $_{1} \quad$ sagte Karl dass $\mathrm{t}_{1}$ keiner dem alten Mann geholfen hat. unfortunately said $K$. that nobody the old man helped has

Again we see that in simplex clauses, movement to SpecFinP comes without any requirements as to operator status, focus status, contrastiveness etc. The same is true for apparent

\footnotetext{
${ }^{11}$ For extensive discussion of German object-es in the pre-field see Frey (this volume). Even if (11) is slightly degraded in comparison with (10) as Eric Fuß (p.c.) feels, (12) is entirely ungrammatical. Judgments may deviate in degree but they do not deviate in direction.
} 
movement from a V2-clause (cf. 13b), which in my view strongly confirms Reis' (1995) claim that such cases have to be analyzed as simplex clauses with a parenthetical insertion (cf. notes 3 and 9). Movement beyond the complementizer dass, however, must target a position with more constraints than SpecFinP. (13c) can only be interpreted with leider being associated with the matrix clause, not with the filler-gap relation which is displayed in the current representation. This position is what Grewendorf (2002) calls SpecFocP and Frey (2005a,b) SpecKontrP. If movement to the left of dass is movement to such a distinct position, the ultimate landing sites must share the properties of SpecFocP / SpecKontrP. Otherwise we would expect effects of improper movement.

I share with Grewendorf's analysis the view that movement to the specifier of dass invokes something like SpecFocP. In a recent account of the that-trace phenomenon, Bayer (2005a,b), I argue that in Bavarian, a dialect which disrespects the DOUBLY-FILLED-COMPFILTER (DFCF), movement to the specifier of dass can only affect wh-phrases which originate in the comment domain of the clause. In the presence of an individual-level predicate, the subject originates in a higher position. Assuming that in this case the feature for checking contrastivity is not available, the expectation is that a dass-trace effect appears. According to my intuitions this expectation is borne out.

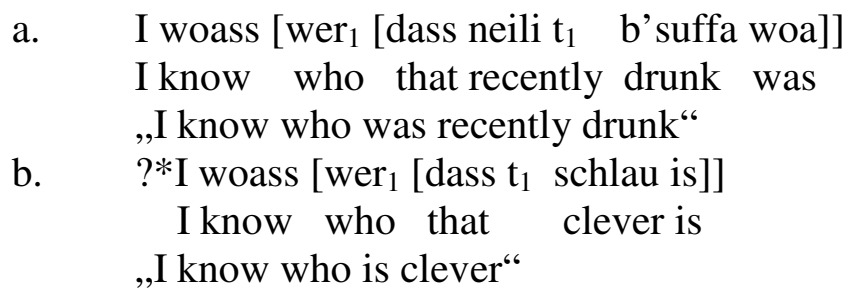

STAGE LEVEL

INDIVIDUAL LEVEL „I know who is clever“

In (14a) the wh-phrase originates in the comment domain following an adverbial stage topic (neili). This entitles the subject to bear an appropriate feature for checking focus/contrast in a position to the left of dass. In (14b) the wh-phrase arguably originates in the topic rather than in the comment domain because no stage topic would be compatible with the individual level predicate. ${ }^{12}$ As a consequence, the wh-phrase does not have the right feature for checking focus/contrast to the left of dass.

Since wh-movement in Standard German, a language which does respect the DFCF, does not show any such contrast, ${ }^{13}$ the conclusion should be that in Standard German, short wh-movement is generally movement to SpecFinP. Grewendorf's generalization in (4a) will then extend to cases in which wh-movement is not triggered by the V2-requirement. To the extent that this step is feasible, the difference between DFCF-languages like modern German and non-DFCF-languages like Bavarian consists of more than just a low-level parameter by which the neutral complementizer dass can either surface or remain silent. Indirect further support for this result will be presented directly.

\footnotetext{
${ }^{12}$ Speakers of English can verify this by considering the semantic ill-formedness of sentences like *There is someone intelligent (which, of course requires ignoring the homophonous but structurally different expression with the meaning "There is someone who is intelligent").

${ }^{13}$ No difference in grammaticality can be observed between (i) and (ii):

(i) Ich weiß wer neulich betrunken war. STAGE LEVEL

I know who recently drunk was

(ii) Ich weiß, wer intelligent ist.

INDIVIDUAL LEVEL

I know who intelligent is
} 


\section{Emphatic topicalization}

Bavarian EMPHATIC TOPICALIZATION as described by Lutz $(1997 ; 2004)$ and Bayer $(2001)$ is a process by which a contrastable XP moves into the specifier of a complementizer, activates a +emphasis feature which is a feature of the root clause and, as a consequence, forces the entire $\mathrm{CP}$ to undergo pied-piping to the specifier of the root clause. ${ }^{14}$ The process is shown with an example from Bayer (2001) in (15).
a. I häid ned g'moant [dass-e an Fünfer kriag] I had $_{\text {subj }}$ not thought that $-\mathrm{I}$ a five get "I didn't think I would get (the rather bad) grade 5"
b. $\quad$ *I häid ned g'moant [an Fünfer 1 [daß-e $t_{1}$ kriag]]
c. $\quad\left[\right.$ An Fünfer 1 [daß-e $\left.\left.\mathrm{t}_{1} \mathrm{kriag}\right]\right]_{2}$ häid-e ned g'moant $\mathrm{t}_{2}$

PIED-PIPING

\section{E-TOPICALIZATION}

Non-contrastive XPs as discussed in (10) through (12) are excluded from emphatic topicalization: *Man 1 dass $\mathrm{t}_{1}$ nicht rauchen soll ...("that one should not smoke"), *Leider ${ }_{1}$ dass $\mathrm{t}_{1}$ keiner dem alten Mann geholfen hat ...("that unfortunately nobody has helped the old man") are sharply ungrammatical. The most remarkable property of emphatic topicalization, however, is that once it has applied it triggers CP pied-piping as seen in (15c). This property is not shared by wh-complements. (14a) is grammatical as it is. ${ }^{15}$ Thus emphatic topicalization must involve another feature than wh-movement. The split C-domain which Grewendorf (2002) proposed for German invites the conclusion that Bavarian involves a third layer above FocP/KontrP, namely an EMPHASIS PHRASE (EmpP). In Bayer (2001) I followed a more conservative approach by which the C-position itself can be associated with features for wh and emp. The expectation is then that either a wh-phrase appears in SpecCP or an emphatic topic but not both. Run-of the mill examples from spoken language seem to confirm this expectation. ${ }^{16}$ I cannot exclude the possibility, however, that wh-phrase and emphatic topic may appear simultaneously. The sentence in (16) strikes me as exceptional but could well be acceptable for certain speakers.

(16) [ An Heinz-Rüdiger $2\left[\text { wer }_{1}\left[\text { dass }\left[\mathrm{t}_{1} \text { vo uns } \mathrm{t}_{2} \text { kennt }\right]\right]_{]}\right]_{3}$ kannt -a-da ned song $\mathrm{t}_{3}$ the Heinz-Rüdiger who that of us knows could subj $-\mathrm{I}-\mathrm{you}$ not tell "As for Heinz-Rüdiger, who of us would know him I could not tell you"

Given the evidence for two distinct landing sites for A'-movement in the left periphery of the German clause, it would not be very surprising to see dialects which allow also for a tripartite structure as in (16). Detailed investigations of speakers' intuitions would be necessary, however, to ground such a conclusion on a serious data base. Whichever answer can be given, the landing site for the pied-piped CP must match that emphatic interpretation that is yielded by e-topicalization. Thus, the pied-piped CP cannot land in SpecFinP but either in SpecKontrP or in an even higher position which is reserved for emphatic material.

\footnotetext{
${ }^{14}$ What the "specifier of the root clause" could be in a split-CP system will be made more precise directly.

${ }_{16}^{15}$ Preposing the wh-CP may apply but does not need to.

${ }^{16}$ See Bayer (2001, note 16).
} 


\section{Conclusion}

With his adaptation of the split-CP hypothesis for German Grewendorf (2002) has initiated a rethinking of traditional assumptions about the left periphery of the German sentence which showed a fairly stable continuum from the topological fields model to generative work in GBtheory. In the previous sections I gave additional evidence in favor of a the split-CP hypothesis while on the other hand trying to overcome certain assumptions concerning operator status and weak crossover which were considered to be constitutive for the approach.

\section{$\underline{\text { References }}$}

Bayer, Josef (1996), Directionality and Logical Form. Kluwer, Dordrecht.

-- (2001), Asymmetry in emphatic topicalization. In: C. Féry and W. Sternefeld (eds.) Audiatur Vox Sapientiae. Akademie-Verlag, Berlin. 15-47.

--, (2005a), Was beschränkt die Extraktion? Subjekt - Objekt vs. Topic - Fokus. In: F.-J. d'Avis (ed.), Deutsche Syntax: Empirie und Theorie. Göteborger Germanistische Forschungen 46. 233-257.

--, (2005b), That-trace without reference to the subject. Invited lecture. 20th Comparative Germanic Syntax Workshop, Tilburg, 10-11 June 2005.

-- and Jaklin Kornfilt (1994), Against scrambling as an instance of move-alpha. In: H. van Riemsdijk and N. Corver (eds.) Studies on Scrambling. De Gruyter, Berlin. 17-60.

Fanselow, Gisbert (1990), Scrambling as NP-movement. In: G. Grewendorf and W. Sternefeld (eds.), Scrambling and Barriers. John Benjamins, Amsterdam. 113-140.

Frey, Werner (2005a) Zur Syntax der linken Peripherie im Deutschen. In: F.-J. d'Avis (ed.), Deutsche Syntax: Empirie und Theorie. Göteborger Germanistische Forschungen 46. 147-171.

-- (2005b), Zur Syntax und Pragmatik der linken Peripherie im Deutschen. Invited lecture. Sonderforschungsbereich 471. Konstanz, 08.12.2005

-- (this volume), How to get an object-es into the German prefield.

Grewendorf, Günther (1988), Aspekte der deutschen Syntax. Gunter Narr Verlag, Tübingen.

-- (2002), Minimalistische Syntax. Francke Verlag, Tübingen.

-- and Joachim Sabel (1999), Scrambling in German and Japanese: adjunction versus multiple specifiers. Natural Language and Linguistic Theory. 17. 1-65.

Haider, Hubert (1993), Deutsche Syntax generativ. Gunter Narr Verlag, Tübingen. 
Hinterhölzl Roland and Diana Pili (2003), Argument shift phenomena across language types. Ms. Humboldt Universität zu Berlin and Università di Siena.

Lasnik, Howard and Timothy Stowell (1991), Weakest crossover. Linguistic Inquiry 22. 687720 .

Lenerz, Jürgen (1994), Pronomenprobleme. In: B. Haftka (ed.), Was determiniert Wortstellungsvariation? Westdeutscher Verlag, Opladen. 161-173.

Lutz, Ulrich (1997), Parasitic Gaps und Vorfeldstruktur. In: F.-J. d'Avis and Ulrich Lutz (eds.) Zur Satzstruktur des Deutschen. Arbeitspapiere des Sonderforschungsbereichs 340, Tübingen. 55-80.

-- (2004), ET, parasitic gaps, and German clause structure. In: H. Lohnstein and S. Trissler (eds.) Syntax and Semantics of the Left Periphery. de Gruyter, Berlin. 265-312.

Müller, Gereon and Wolfgang Sternefeld (1993), Improper movement and unambiguous binding. Linguistic Inquiry 24. 461-507.

Reis, Marga (1995), Extractions from Verb-Second Clauses in German? In: U. Lutz and J. Pafel (eds.) On Extraction and Extraposition in German. John Benjamins, Amsterdam. 45-88.

Rizzi, Luigi (1997), The fine structure of the left periphery. In: L. Haegeman, (ed.), Elements of Grammar. Kluwer, Dordrecht. 281-337.

Travis, Lisa (1984), Parameters and Effects of Word Order Variation, Ph.D. dissertation, MIT Cambridge, Massachusetts. 